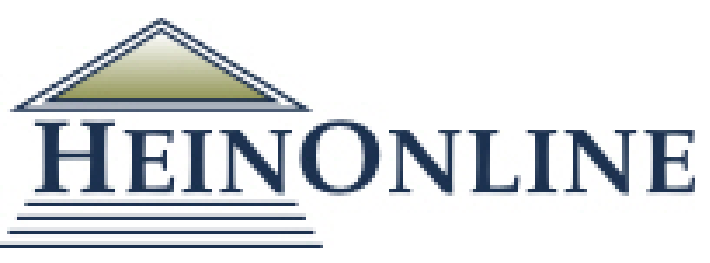

Content downloaded/printed from

HeinOnline

Wed Sep 18 20:18:16 2019

Citations:

Bluebook 20th ed.

Aisosa Jennifer Isokpan; Ebenezer Durojaye, The Child's Right to Basic Education in Nigeria: A Commentary on the Decision in Serap v. Nigeria, 26 Afr. J. Int'I \& Comp.

L. 639 (2018).

APA 6th ed.

Isokpan, A.; Durojaye, E. (2018). The child's right to basic education in nigeria:

commentary on the decision in serap v. nigeria. African Journal of International and Comparative Law, 26(4), 639-648.

ALWD

Isokpan, A.; Durojaye, E. (2018). The child's right to basic education in nigeria: commentary on the decision in serap v. nigeria. Afr. J. Int'l \& Comp. L., 26(4), 639-648.

Chicago 7th ed.

Aisosa Jennifer Isokpan; Ebenezer Durojaye, "The Child's Right to Basic Education in Nigeria: A Commentary on the Decision in Serap v. Nigeria," African Journal of International and Comparative Law 26, no. 4 (2018): 639-648

McGill Guide 9th ed.

Aisosa Jennifer Isokpan \& Ebenezer Durojaye, "The Child's Right to Basic Education in Nigeria: A Commentary on the Decision in Serap v. Nigeria" (2018) 26:4 African J of Intl \& Comparative L 639.

MLA 8th ed.

Isokpan, Aisosa Jennifer, and Ebenezer Durojaye. "The Child's Right to Basic Education in Nigeria: A Commentary on the Decision in Serap v. Nigeria." African Journal of International and Comparative Law, vol. 26, no. 4, 2018, p. 639-648. HeinOnline.

OSCOLA 4th ed.

Aisosa Jennifer Isokpan and Ebenezer Durojaye, 'The Child's Right to Basic Education in Nigeria: A Commentary on the Decision in Serap v. Nigeria' (2018) 26 Afr J Int'l \& Comp L 639

-- Your use of this HeinOnline PDF indicates your acceptance of HeinOnline's Terms and Conditions of the license agreement available at https://heinonline.org/HOL/License

-- The search text of this PDF is generated from uncorrected OCR text.

-- To obtain permission to use this article beyond the scope of your license, please use: Copyright Information

Use QR Code reader to send PDF to your smartphone or tablet device 


\title{
THE CHILD'S RIGHT TO BASIC EDUCATION IN NIGERIA: A COMMENTARY ON THE DECISION IN SERAP v. NIGERIA
}

\author{
AISOSA JENNIFER ISOKPAN * and EBENEZER DUROJAYE**
}

\section{INTRODUCTION}

The right to education is not justiciable in Nigeria by virtue of it being included in Chapter II of the Constitution of the Federal Republic of Nigeria 1999 (as amended) (CFRN 1999) as a directive principle of state policy. This is evidenced in the case of Badejo v. Federal Ministry of Education, ${ }^{1}$ where the applicant claimed that as a result of the discriminatory conduct of the respondents she was denied her right and the chance to be considered for admission into one of the Federal government colleges in Nigeria. Her application as well as her appeal was dismissed by the High Court and the Court of Appeal.

Nigeria is a party to several international human rights instruments that guarantee the right to basic education such as the International Covenant on Economic, Social and Cultural Rights (ICESCR) ${ }^{2}$ the African Charter on Human and Peoples' Rights (African Charter), ${ }^{3}$ the Convention on the Rights of the Child $(\mathrm{CRC})^{4}$ as well as the African Charter on the Rights and Welfare of the Child (ACRWC). ${ }^{5}$ The provisions of the CRC as well as the ACRWC have been incorporated into the Child's Rights Act 2003 (CRA 2003). In line with its

* (LLB (University of Benin, Nigeria), LLM (Cape Town); Graduate Lecturing Assistant, University of the Western Cape, Cape Town, South Africa.

** ((LLB (Lagos), LLM, LLD (Free State); Project Head and Senior Researcher, Socio-economic Rights Project, Dullar Omar Institute, Faculty of Law, University of the Western Cape, Cape Town, South Africa.

1 (1990) 4 NWLR (Pt. 143) 354. This case is based on the 1979 Constitution of Nigeria which has similar provisions as the CCFRN 1999.

2 Adopted by the General Assembly of the UN on 19 December 1966.

3 Adopted by the Organisation of African Unity Assembly in 1981 and entered into force on 21 October 1986.

4 Adopted by the UN General Assembly Resolution 44/25 on 20 November 1989 and entered into force on 2 September 1990.

5 Adopted by the Organisation of African Unity on 11 July 1990 and entered into force in November 1999 AU Doc. CAB/LEG/24.9/49 (1990).

African Journal of International and Comparative Law 26.4 (2018): 639-648

Edinburgh University Press

DOI: $10.3366 /$ ajicl.2018.0252

(C) Edinburgh University Press

www.euppublishing.com/ajicl 
obligation to provide basic education, the legislature has enacted the Compulsory, Free Universal Basic Education Act (UBE Act). The CRA $2003^{6}$ as well as the UBE Act guarantee to children in Nigeria the right to basic education as defined under the UBE Act. In spite of these legislative provisions intended to create an enforceable right, the state of basic education after more than a decade of the enactment of the CRA 2003 and the UBE Act makes it quite uncertain if the child's right to basic education indeed exists in Nigeria.

The purpose of this article is to critically review the case of Registered Trustees of the Socio-economic Rights and Accountability Project (SERAP) v. Federal Republic of Nigeria and Universal Basic Education Commission $(U B E C)^{7}$ (SERAP v. Nigeria) which was decided by the Economic Community of West African States (ECOWAS) Community Court of Justice. While to an extent this case is a precedent heralding an enforceable right to education for Nigerians, on the other hand it has failed to address the major hindrances to the realisation of the child's right to basic education in Nigeria. It leaves much to be desired with respect to the justiciability of as well as the obligation of the Nigerian government towards the realisation of the child's right to basic education. Considering that the complaint in this case relates to the misappropriation of funds meant for basic education affecting children, the arguments will mainly relate to the child's right to basic education.

\section{THE FACTS AND DECISION IN SERAP v. NIGERIA}

The case of SERAP v. Nigeria centred around the denial of the right to education to the people of Nigeria as guaranteed by Article 17 of the African Charter. Article 17 provides thus:

1. Every individual shall have the right to education. 2. Every individual may freely, take part in the cultural life of his community. 3. The promotion and protection of morals and traditional values recognized by the community shall be the duty of the State.

Although the African Commission is yet to provide any clarification on the content and scope of the right, one can be guided by the General Comments issued by the Committee on Economic, Social and Cultural Rights (CESCR). In its General Comment 13, the Committee has noted that the essential elements of the right to education include availability, accessibility, acceptability and adaptability. ${ }^{8}$ The Committee notes that states have an obligation to ensure the availability of functioning educational institutions and programmes, ensuring that education institutions are accessible without discrimination and that the forms, substance

6 Section 15 CRA 2003 and section 2 of the UBE Act.

7 Suit No.: ECW/CCJ/AAP/12/070808 Judgment No. ECW/CCJ/JUD/07/10 30 November 2010.

8 Committee on Economic Social and Cultural Rights, General Comment No. 13 'The Right to Education' (Article 13), adopted at the 21st session of the Committee on 8 December 1999 , para. 6. 
and curriculum of education have to be acceptable. Further discussion on these elements is provided below.

The genesis of the matter before the court centred on the mismanagement of funds allocated for basic education in ten states of Nigeria, which had the effect of denying over five million children access to basic education. The plaintiff also alleged other factors such as failure to train more teachers and non-availability of books and other teaching materials as militating against access to basic education in Nigeria. The federal government was alleged to have contributed to these problems by failing to seriously address all allegations of corruption at the highest levels of government and the levels of impunity that facilitate corruption in Nigeria. This, they allege, has contributed to a denial of the right to education. Relying on Article 4(g) of the Revised Treaty of the Economic Community of West African States (ECOWAS) as well as Article 17 of the African Charter, the plaintiff submitted that the first defendant had violated the right to education. The relief sought among others was a declaration that every Nigerian child is entitled to free, compulsory education by virtue of Article 17 of the African Charter, section 15 of the CRA 2003 and section 2 of the UBE Act.

The second defendant challenged the jurisdiction of the court on the ground that the CRA 2003 and the UBE Act are municipal laws and not treaties, hence not within the jurisdiction of the court. It also contended that the educational objective of Nigeria is contained in section 18(1) which is a directive principle and not justiciable or enforceable and cannot be determined by the court. In response, the plaintiff contended that the argument is misconceived as the right to education contained in Chapter II of the Nigerian constitution is equally guaranteed by international instruments such as the ICESCR and the African Charter to which Nigeria is a party. In its ruling on the preliminary objection, the court noted that though the plaintiff factually based its claim on the CRA 2003 and the UBE Act, it relied primarily on the ICESCR and Article 17 of African Charter to allege a breach of the right to education and not Chapter II of the Constitution. The court thus held that it is empowered by Article 4(g) of the Revised Treaty of ECOWAS to apply the provisions of the African Charter which guarantee the right to education. It ruled that since the plaintiff's application is based on the African Charter, the contention of the second defendant that the right to education is not justiciable as it falls within the directive principles of state policy cannot hold. In other words, every Nigerian has a justiciable right to education as guaranteed by Article 17 of the African Charter.

In its judgment on the main issues, the court noted that the defendants did not contest the fact that every Nigerian child is entitled to free and compulsory basic education. What they said was that the right was not justiciable in Nigeria. Restating its earlier ruling on the objection, the court held that the child's right to basic education is justiciable under the African Charter. With respect to the issue of corruption claimed to have resulted in a denial of the right to education, the court held that the mismanagement of funds allocated to the education sector though having a negative impact on education does not amount to a denial of the right to education. 


\section{DISCUSSION}

\section{A. Justiciability of the Right to Education}

In the SERAP case, the court held that the child has a justiciable right to education as guaranteed by Article 17 of the African Charter. Due to the non-justiciability of the right to education, the plaintiff primarily based its claim on Article 17 of the African Charter. This decision might be good enough as a restatement of the fact that every Nigerian has enforceable rights under the African Charter which has not only been ratified but also domesticated by Nigeria. The decision does not uplift the status of the right to education or other socio-economic rights guaranteed in the African Charter considering the decision of the court in the case of Abacha v. Fawehinmi. ${ }^{9}$

It has been noted that despite the importance of international and regional law, treaty norms have greater impact when they are made part of domestic law through legislation or jurisprudence through which they acquire a special status that cannot be changed. ${ }^{10}$ The CFRN 1999 in section 12 provides that no treaty between the Federation and any other country shall have the force of law to the extent to which any such treaty has been enacted into law by the National Assembly. This is exactly what the National Assembly has done with the enactment of the African Charter on Human and Peoples' Rights (Ratification and Enforcement) Act. ${ }^{11}$ Section 12(2) also provides that the National Assembly may make laws for the Federation or any part thereof with respect to matters not included in the Exclusive Legislative List for the purpose of implementing a treaty. This is also reflected in the CRA 2003 as well as the UBE Act in line with its obligations under the CRC, the ACRWC, the African Charter and the ICESCR.

In the case of Abacha v. Fawehinmi, the Supreme Court quoted with approval the decision of the Privy Council in the case of Higgs and Another v. Minister of National Security \& Ors where the council noted that:

Treaties formed no part of domestic law unless enacted by the legislature. Domestic courts had no jurisdiction to construe or apply a treaty, nor could unincorporated treaties change the law of the land. They had no effect upon citizen's rights and duties in common or statute law. They might have an indirect effect upon the construction of statutes or might give rise to a legitimate expectation by citizens that the government, in its act effecting them, would observe the terms of the treaty.

The Supreme Court noted that this is the position not only in England but also in Nigeria. It was thus held that the African Charter which is incorporated into

9 (2000) 6 NWLR (Part 660) 228.

10 C. Heynes and F. Viljoen, 'The impact of the United Nations treaties on the domestic level', 23 Human Rights Quarterly (2001), pp. 483-535, at pp. 487-8; C. Onyemelukwe 'Access to antiretroviral drugs as a component of the human right to health in international law: examining the application of the right in Nigerian Jurisprudence', 7 AHRLJ (2007), pp. 446-74, at p. 462.

11 Cap 10, Laws of the Federation of Nigeria 1990. This is the law that domesticated the provisions of the African Charter in Nigeria in 1983 through Decree 107 of 1983. 
our laws becomes binding and our courts must give effect to it like all other laws falling within the judicial powers of our courts. The court nevertheless held that the provisions of the African Charter are not superior to the Constitution. It in effect means that claims to justiciable socio-economic rights under the African Charter cannot stand considering that it will be inconsistent with the provisions of section $6(6)(\mathrm{c})$ of the CFRN 1999 which ousts the jurisdiction of the courts in respect of matters contained in Chapter II of the Constitution. In effect, the decision that the child's right to education is justiciable under the African Charter cannot hold in the light of the inconsistency rule of the CFRN $1999^{12}$ and the decision of the Supreme Court in the case of Abacha v. Fawehinmi.

The decision does not promote the justiciability of the child's right to basic education under the CRA 2003 and the UBE Act despite the fact that a declaration to that effect was claimed by the plaintiff. Even though the right to education is generally non-justiciable in the Nigerian Constitution, the CRA 2003 as well as the UBE Act to a degree shows an intention on the part of the government to prioritise basic education. Considering that the major issue that prompted the plaintiff to institute this action centred around corruption hindering the realisation of the child's right to basic education, the case of SERAP v. Nigeria was an opportunity for the child's right to basic education to be elevated beyond just a legislative enactment through judicial activism. The decision could have set the pace for the Nigerian judiciary to take a more progressive view of the status of the child's right to basic education in Nigeria based on the CRA 2003 and the UBE Act.

\section{B. Corruption and the Denial of the Right to Education}

The decision given by the ECOWAS court missed a vital opportunity to address the issue of corruption which is a major problem hindering the realisation of the child's right to basic education in Nigeria. Disappointingly, the court held that findings of corruption will not amount to a denial of the right to education. In its words:

Admittedly, embezzling stealing or even mismanagement of funds meant for the education sector will have a negative impact on education since it reduces the amount of money made available to provide education to the people. Yet it does not amount to a denial of the right to education, without more. The reason is not far to seek. The Federal Government of Nigeria has established institutions, including the 2 nd defendant to take care of the basic education needs of the people of Nigeria. It has allocated funds to these institutions to carry out their mandate. We believe these are all geared towards fulfilling the right to education. Some officers charged with the duty

12 Section 1(3) of the CFRN 1999 provides that if any other law is inconsistent with the provisions of the constitution, the constitution shall prevail and that other law shall to the extent of its inconsistency be void. 
of implementing the education mandate, are said to have misused, misapplied, embezzled or even stolen part of the funds. The Federal Government and the 2nd defendant are said to have failed to act against such persons and for that reason, they are said to have denied the right of the peoples of Nigeria to education. There must be a clear linkage between the acts of corruption and a denial of the right to education. In a vast country like Nigeria, with her massive resources, one can hardly say that an isolated act of corruption contained in a report will have such devastating consequence as a denial of the right to education, even though as earlier pointed out it has a negative impact on education. ${ }^{13}$

The reasoning of the court is misconceived. It is not in issue that the realisation of socio-economic rights including the right to education is highly dependent on availability, budgeting and the use of resources. In a situation of widespread corruption in the use of funds allocated for the fulfilment of socio-economic rights, the enjoyment of the right is compromised. Indeed it has been noted that chronic corruption is largely responsible for the failure of African countries to meet their obligations to realise the socio-economic rights of their people. ${ }^{14}$ The Committee on the Rights of the Child has noted that states in which corruption is widespread cannot comply with their obligation to fulfil the socio-economic rights of children in line with its obligation in Article 4 of the CRC. ${ }^{15}$ According to the Maastricht Guidelines, violation of socio-economic rights can occur through the direct action of states or other entities insufficiently regulated by states. ${ }^{16}$ One of such violations listed includes the reduction or diversion of specific public expenditure, when such reduction or diversion results in the non-enjoyment of such rights. ${ }^{17}$ It has been noted that in realising the right to health progressively, where the benchmark is not reached because of corruption, it is an indication that the state has failed to comply with its international right to health obligations. ${ }^{18}$ In the SERAP case, the funds which were misappropriated had the effect of denying over five million children access to education.

13 Para. 19

14 See E. Durojaye, 'Corruption as a threat to human security in Africa', in A. Abass (ed.), Protecting Human Security in Africa (Oxford University Press, 2010), pp. 217-46.

15 Concluding Observations of the Committee on the Rights of the Child: Georgia CRC/C/15/Add.124 28 June 2000, para. 18; Concluding Observations of the Committee on the Rights of the Child: Kenya, CRC/C/15/Add.160, 7 November 2001, para. 9; Concluding Observations of the Committee on the Rights of the Child: Tajikistan, CRC/CX/15/Add.139, 23 October 2000, para. 5.

16 See the Maastricht Guidelines on Violations of Economic, Social and Cultural Rights, 26 January 1997, para. 14.

17 Maastricht Guidelines. para. 14(g).

18 United Nations Economic and Social Council Report of the Special Rapporteur on the Right of Every One to the Enjoyment of the Highest Attainable Standard of Physical and Mental Health, 3 March 2006, E/CN.4/2006/48, para. 44. 
In determining if a particular corrupt practice violates human rights, it is important to establish the scope and content of the human rights obligation. ${ }^{19}$ The essential feature of basic education has been structured into a ' 4 A' scheme by the United Nations Special Rapporteur on the Right to Education. They include availability, accessibility, acceptability and adaptability. ${ }^{20}$ Availability means that all necessary infrastructure, learning facilities and personnel are in place. Accessibility means that children have a right of access that is without discrimination, is affordable and is within a reasonable distance. ${ }^{21}$ As noted earlier, the CESCR, emphasising the importance of the four features in General Comment $13,{ }^{22}$ explains acceptability to mean that the form and substance of education curricula and teaching methods have to be relevant, culturally appropriate and of good quality. ${ }^{23}$ Adaptability requires that education be flexible enough to meet the changing needs of societies, communities and students in their diverse social and cultural settings. ${ }^{24}$

A state has the obligation to respect, protect and fulfil ${ }^{25}$ the essential features of the right to education. ${ }^{26}$ The obligation to respect requires the state to refrain from acts or omissions that may deprive individuals of the enjoyment of their rights. The obligation to protect requires the state to prevent violation of the rights of individuals by third parties. Failure on the part of government to comply with this level of obligation can be a determinant of state responsibility in corruption cases. Failure to check corrupt practices on the part of government officers or private actors can lead to the violation of human rights. ${ }^{27}$ In line with this obligation, the duty of the Federal government of Nigeria does not end with the allocation of the funds meant for the UBE scheme; it must make an effort to ensure that such funds are used for the appropriate purpose. The obligation to fulfil requires the state to take adequate legislative, budgetary and administrative measures towards the fulfilment of these rights. ${ }^{28}$

Financing is essential to the maintenance of education, ${ }^{29}$ and as educational institutions occupy a large space in the public sector, it creates many incentives

19 Corruption and Human Rights: Making the Connection (International Council on Human Rights Policy, Switzerland, 2009), http://www.ichrp.org/files/reports/40/131_web.pdf (accessed 20 June 2016), p. 24.

20 United Nations Economic and Social Council Preliminary Report of the Special Rapporteur on the Right to Education, Ms Katarina Tomasevski, submitted in accordance with the Commission on Human Rights resolution 1998/33, paras 50-74.

21 M. Verheyde, Commentary on the United Nations Convention on the Rights of the Child (Article 28: The Right to Education) (Martinus Nijhoff, 2006), pp. 15-17.

22 General Comment 13, para. 6.

23 General Comment 13, para. 6(c).

24 General Comment 13, para. 6(d).

25 General Comment 13, para 46.

26 General Comment 13, para. 50.

27 Supra, note 19, p. 25.

28 See Maastricht Guidelines on Violations of Economic, Social and Cultural Rights, 26 January 1997, para. 6.

29 See Report of the Special Rapporteur on the Right to Education, Vernor Muñoz Villalobos, 17 December 2004, E/CN.4/2005/50, para. 49. 
and opportunities for corruption in the management of resources budgeted for its realisation which can affect the enjoyment of the right. ${ }^{30}$ Corruption in the education system could play out in reduced spending on infrastructure due to the embezzlement of funds, the recruitment of unqualified teachers, discrimination in admission and charging fees indiscriminately. These have a negative impact on the availability, accessibility, acceptability and adaptability requirements of the right to education as noted by the Special Rapporteur and the CESCR. It also has long-term effects of harming the quantity and quality of education delivery over time as well as having a disproportionate effect on people who can only break the cycle of poverty through access to quality education. ${ }^{31}$

In the SERAP case, the alleged corrupt misappropriation of funds allocated to ten states of the Federal Republic of Nigeria had the effect of depriving over five million children of access to education. The decision of the court in effect absolved the Federal government of Nigeria of its duty to protect the right to education by ensuring that government officials do not infringe on the rights through misappropriation of funds allocated for its realisation. It rather limits government responsibility for funding education simply to allocation. No matter how much is allocated, if proper monitoring is not carried out to ensure its effective use, the effort can simply be equated to zero.

Indeed, corruption is one of the reasons for the sorry state of basic education currently found in Nigeria as a result of the mismanagement and embezzlement of funds reserved for the development of the educational sector. ${ }^{32}$ This is shown by the high level of out-of-school children (OOSC). An estimated 42 per cent of children of primary school age amounting to about 10.5 million are out of school. ${ }^{33}$ The high OOSC burden is an evidence of Nigeria's failure to meet the Education for All and Millennium Development Goals with respect to universal basic education.

\section{SOME OBSERVATIONS}

Though the right to education is guaranteed in international and regional human rights instruments, its full realisation is dependent on its effective implementation at the national level through the adoption of constitutional provisions, legislation and policies. It is, however, not enough to have a legal right, enforcement mechanisms must also be in place in case of infringement. In other words, the right to education should be justiciable.

With respect to the issue of justiciability of the right to education, a lot still needs to be done by the Nigerian courts. The Nigerian courts have not made

30 Supra, note 19 , p. 56.

31 Supra, note 19 , p. 57.

32 F. Arong and M. Ogbadu 'Major causes of declining quality of education in Nigeria from an administrative perspective: a case study of Dekina local government area', 6(3) Canadian Social Science (2010), pp. 183-98, at p. 195.

33 'Accelerating Progress to 2015: Nigeria', Report series to the United Nations Special Envoy for Global Education (2013), available at http://educationenvoy.org/wp-content/uploads/ 2013/07/NIGERIA-UNSE-FINAL.pdf (accessed 20 June 2016), p. 3. 
any commendable efforts through judicial activism to ensure the justiciability of socio-economic rights in Nigeria. There is a need for the courts to take a clue from the Indian Supreme Court which has creatively and successfully made socioeconomic rights justiciable through its emphasis on the interdependence of human rights. The Constitution of India, like the Nigerian Constitution, contains socioeconomic rights which are stated to be non-justiciable. However, the Indian courts have expanded the scope of justiciable rights to include socio-economic rights through its expansion of the scope of the right to life contained in Article 21 of the Constitution in the case of Maneka Ghandi v. Union of India. ${ }^{34}$ Also, in the case of Francis Coralie v. Union Tertiary of India ${ }^{35}$ the Supreme Court held that the right to life includes the right to live with human dignity and all that goes with it, namely the bare necessities of life such as adequate nutrition, clothing and shelter and facilities for reading and writing and expressing one's self in diverse forms. The court has also held the right to livelihood, ${ }^{36}$ food, ${ }^{37}$ shelter $^{38}$ and health ${ }^{39}$ as justiciable socio-economic rights.

With respect to the right to education, in Mohini Jain v. State of Karnataka ${ }^{40}$ the court held that the state has a duty to provide education so that the citizens can enjoy their right to education. In Unni Krishnan JP v. State of Andhra Pradesh $\&$ Others $^{41}$ the court held that a child deprived of the right to education can issue a writ of mandamus against the appropriate authority for the enforcement of that right. The Unni Krishnan case resulted in the inclusion of an enforceable right to education in Article 21 of the Indian Constitution through the 93rd amendment in $2002 .{ }^{42}$ Article $21 \mathrm{~A}$ of the Constitution provides that the state shall provide free and compulsory education to all children from the age of six to 14 years in such manner as the state may determine by law. Article 45 was also amended to accommodate the obligation of the state to provide early childhood care and education to all children until they reach six years of age. ${ }^{43}$ Article 51 was also amended to impose the responsibility on parents and guardians to provide opportunity for the education of a child between the ages of six and 14 years. ${ }^{44}$ The right to education progressed into the enactment of the Right to Free and Compulsory Education Act 2009. This Act was used to explain the modalities for the implementation of the child's right to education as contained in the Indian Constitution. This is unlike the UBE Act which guarantees a right that is stated to be non-justiciable in the Constitution.

34 (1978) 1 SCC 248.

35 (1981) 2 SCR 516529.

36 Olga Tellis v. Bombay Municipal Council (1985) 2 SCR Supp. 51, 83.

37 See the case of People's Union of Civil Liberties (PUCL) v. Union of India, Writ Petition (Civil) No. 196 of 2001.

38 Olga Tellis v. Bombay Municipal Council (1985) 2 Supp. SCR 51; Shanti Star Builders v. Narayan $K$. Totame (1990) 1 SCC 520.

39 Consumer Education and Research Center v. Union of India (1995) 3 SCC 42.

40 (1992) 3 SCC 666.

41 (1993) SCC (1) 645.

42 See Article 2 of the Constitution (Eighty-Sixth Amendment) Act 2002.

43 See section 3 of the 86th Amendment.

44 See section 4 of the 86th Amendment. 
648 Aisosa Jennifer Isokpan and Ebenezer Durojaye

\section{CONCLUSION}

Nigeria has made a step forward to realise the right to education with the enactment of the CRA 2003 and the UBE Act. The case of SERAP v. Nigeria missed the opportunity to create a necessary precedent for the justiciability of the child's right to basic education in Nigeria. It therefore follows that the controversy with respect to the justiciability of the child's right to basic education can only be laid to rest if the Constitution is amended to reflect it just as in the Indian Constitution. 